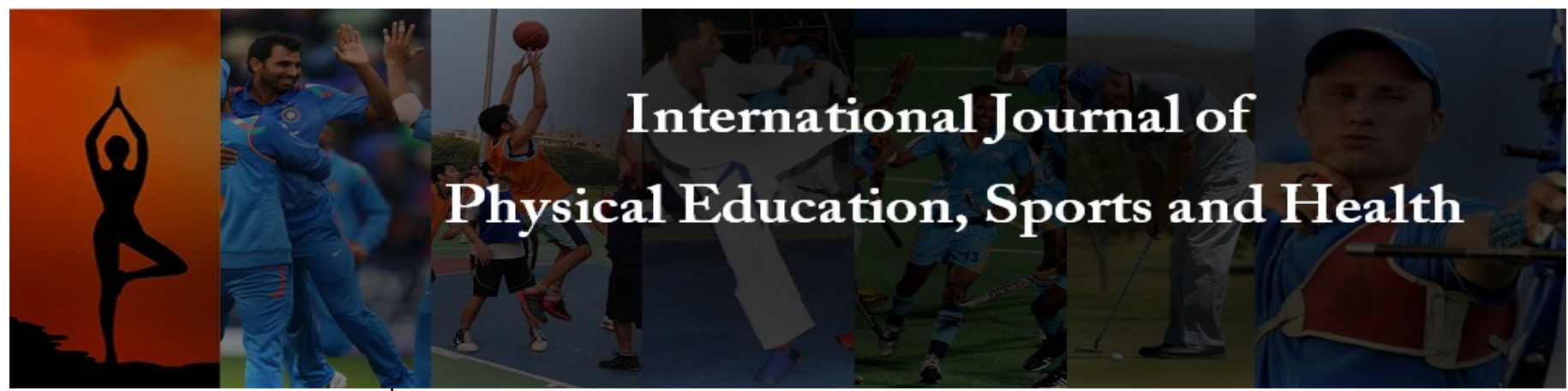

P-ISSN: 2394-1685

E-ISSN: 2394-1693

Impact Factor (ISRA): 5.38

IJPESH 2020; 7(6): 01-03

(C) 2020 IJPESH

www.kheljournal.com

Received: 01-09-2020

Accepted: 02-10-2020

\section{Kousik Biswas}

Research Scholar, Department of Physical Education, University of Kalyani, Kalyani, Nadia, West Bengal, India

Dr. Susanta Sarkar

Associate Professor, Department of Physical Education,

University of Kalyani, Kalyani,

Nadia, West Bengal, India
Corresponding Author: Kousik Biswas

Research Scholar, Department of Physical Education, University of Kalyani, Kalyani, Nadia, West Bengal, India

\section{Facilities of white water rafting in West Bengal}

\author{
Kousik Biswas and Dr. Susanta Sarkar
}

\section{Abstract}

The objective of the study was to focus on the existing facilities and scope for White Water Rafting, and the level of facilities available of standard equipment and training in West Bengal. Checklist interview and valid official data was analysed during the survey study. Result was found that few Non-Government agencies conducted white water rafting for commercial purpose only. They used both Indian and international rafting gears but amount of equipment was insufficient, no such Government or NonGovernment Institution for White water Rafting training. West Bengal Government do not have any equipment for White Water Rafting. This study may raise the relevant points which are to be addressed by the appropriate authority to elevate the prospect of White Water Rafting in the state of West Bengal.

Keywords: White water rafting, equipment, facilities, West Bengal.

\section{Introduction}

Adventure is an exciting experience that is typically a bold, sometimes risky, undertaking. Adventures may be activities with some potential for physical danger. Engaging ourselves in an unusual and exciting, typically hazardous, experience or activity. This is genetically transferred from ancient people.

White Water Rafting is the activities perceived as having high level of inherent danger. Sometimes it is called River rafting i.e. one type of adventure sports where the risk factor is too high. Now White Water Rafting is popular worldwide as well as in India and West Bengal. West Bengal Mountaineering and Adventure Sports Foundation were functioning under the Youth Services Department, Government of West Bengal in the year 2006. The aims and objectives of this Foundation is to help and encourage the Youth of this State in 'Adventure Sports', Expedition and Exploration of diverse nature and in fostering among them a spirit of camaraderie, good neighbourly relations, sacrifice for a noble cause, self-discipline, selfrespect and respect for freedom and integrity of the nation. Further, the Foundation will support, promote and execute schemes for mountaineering, skiing, rock-climbing, altitude trekking, hang gliding, jungle safari, coastal trekking, river rafting, and sea surfing including exploration under the seas, cycling, motor cycling, touring, aero sports for the youth.

\section{Purpose of the study}

- To focus on the existing facilities and scope for White Water Rafting, and the level of facilities available in West Bengal.

- Availability of standard equipment in White Water Rafting in West Bengal.

- The role of Central and State government assistance in the programs of White Water Rafting.

- The assistance of non-government organization in the programs of White Water Rafting.

- To assess the status of training facilities in White Water Rafting by the government and non-government agencies.

\section{Methodology}

This chapter includes the information about White Water Rafting. It compiles the basic and advanced techniques adopted, the required equipment used and the preparatory part for the White Water Rafting. This chapter also include the criteria measured and the different sources of data explored for this survey study. 


\section{Method of collecting data}

Following tools were used for the collection of data:

\section{Primary source}

a. Interview:

Interviews were also applied to collect the necessary information, the interview designed especially for White Water Rafting and the research scholar has also collected the important information through interviews of various great personalities in this fields.

\section{Secondary source:}

a. Documents - (Government \& Non- Government) The research scholar visited various Government and Non-Government Agency's offices to gather information concerning the research study. They were encouraged to answer freely. Report was cross- checked among the concerned persons.

b. Journal

Various Journals on White Water Rafting were consulted to collect relevant data.

c. Books

d. News Papers

A number of dailies were read to collect relevant information regarding the facts and figures on White Water Rafting.

e. Checklist

Checklists provided by Government and NonGovernment sources were critically examined to collect the data relevant to the present study.

\section{Presentation of data}

Different data of White Water Rafting are presented accordingly.

- List of available equipment

- Training facilities

- Training programme

- The Governmental patronage

- The role played by Non- government organizations

- The achievement Status

- Etc.

\section{Result and Discussion}

Sites of white water rafting in West Bengal

White Water Rafting in Teesta has been introduced by erstwhile DGHC (Darjeeling Gorkha Hill Council, now GTA) in 1991 and has been consistently gaining popularity. It is now under the supervision of West Bengal Mountaineering and Adventure Sports Foundation (WBMASF).

River Teesta originates from Tso Lhamo Lake in North Sikkim at an altitude of over 5,330 meters, while Rangeet originates from a glacier of Mount Kabru in the lower Kanchenjunga region. Teesta eventually forms the boundary between Darjeeling district (of West Bengal) and Sikkim. Both Teesta and Rangeet meet at a place close to Teesta Bazar near the plains. This meeting point is known as Triveni. While rafting also takes place at Triveni, the most popular place for rafting is on river Teesta is Melli.
The most popular Section on Teesta for rafting -

For non-swimmers:

1. Melli to 29th Mile (1.5 hours)

2. Melli to Kalijhora (3 hours)

For swimmers only:

1. Tarkhola to Melli (2 hours)

2. Tarkhola to 29 Mile (3 hours)

3. Starts at 7th Mile and ends at Labarbote near Sikkim Bengal border (4-5 kms).

\section{White water rafting competition in West Bengal}

First rafting expedition on the Teesta Rangeet held in 1986. After that Rafting set up grow up mainly for Tourist recreation purpose.

\section{Training programme of white water rafting in India and West Bengal}

There were some institute those conducted White water rafting course. The institute and course details are as follows: National Institute of Mountaineering and Allied Sports (Dirang, West Kameng, and Arunachal Pradesh) conducted following courses-

a. Basic White Water Rafting course (10 Days), eight times in a year. Course cost Rs.12000.

b. Intermediate White Water Rafting course (12 Days), four times in a year. Course Fees Rs.15000.

c. Rafting expedition course (Kameng river in arunachal Pradesh), twice in a year. Course cost Rs.25000.

Atalbihari Vajpayee Institute of Mountaineering and Allied Sports (Manali, Himachal Pradesh) conducted Basic and Advanced Rafting Course.

National lnstitute of Watersports (Panjim, Goa) conducted White water rafting course.

Jawahar Institiute of Mountaineering \& Winter Sports (Pahalgam, Jammu \& Kashmir) conducted White water rafting in the Lidder River at Pahalgam on special request from agencies.

Indian Himalayan Center for Adventure \& Eco Tourism (Govt. Of Sikim) conducted Basic course, Intermediate course and Advanced course in White Water Rafting.

In West Bengal there was no such Institution for White Water Rafting Training.

List of non-government agency who conducted white water rafting for tourists in West Bengal

Tista Rangeet River Rafters Association, National Highway10, Dansong Forest Kalimpong, West Bengal, 734312.

Kingfisher River Rafting \& Rescue Group, National Highway-10, Dansong Forest Kalimpong, West Bengal, 734312.

Happy Adventure and Rescue Group. Everest River Rafting \& Rescue, Rafting point $7^{\text {th }}$ Mile, National Highway- 10, Kirney Bazar, Kalimpong, West Bengal.

Everest River Rafting \& Rescue, Rafting point $7^{\text {th }}$ Mile, National Highway- 10, Kirney Bazar, Kalimpong, West Bengal.

Table 1: Equipment of white water rafting in West Bengal

\begin{tabular}{|c|c|c|c|}
\hline \multirow{2}{*}{ Sl. No. } & \multirow{2}{*}{ Equipment } & \multirow{2}{*}{ Manufactured } & \multicolumn{2}{c|}{ Quantity in West Bengal } \\
\cline { 3 - 5 } & Inflatable rafting boat & NRS-41 Pcs. Achillies -11 Pcs. Indian- 5 Pcs. & Non govt. organization \\
\hline 1 & Life jacket & NRS-213 Pcs. Indian-192 Pcs. & Nil \\
\hline 3 & Helmet & NRS-50 Pcs. Indian- 170 Pcs. & Nil \\
\hline
\end{tabular}




\begin{tabular}{|c|c|c|c|c|}
\hline 4 & Carbon paddle & NRS-244 Pcs. Indian-55 Pcs. & Nil & 294 \\
\hline 5 & Wet suit & & Nil & 0 \\
\hline 6 & Dry suit & & Nil & 0 \\
\hline 7 & Rescue throw bag & NRS-21 Pcs. Indian-25 & Nil & 46 \\
\hline 8 & Walkie takie & & Nil & Nil \\
\hline 9 & GPS & & Nil & Nil \\
\hline 10 & Ore (Big paddle) & Indian-58 Pcs. & Nil & 58 \\
\hline
\end{tabular}

\section{Conclusion}

In West Bengal few Non-Government agencies conducted white water rafting for commercial purpose only. They used both Indian and international rafting gears but amount of equipment was insufficient.

In West Bengal there was no such Government or NonGovernment Institution for White water Rafting training.

West Bengal Mountaineering and Adventure Sports Foundation's do not have any equipment for White Water Rafting.

\section{References}

1. Garrett HE. Statistics In Psychology \& Education. New Delhi: Paragon International Publishers 2005.

2. Office of the APA Style. Publication Manual of the Americal Psychological Association (7th ed.). Washington DC: American Psychological Association 2020.

3. Barrow HM, McGee R. A practical approach to measurement in physical education (Third ed.). Philadelphia: Lea \& Fibiger 1979.

4. Chawdhury TP. Adventure Sports. New Delhi: National Book Trust 2014.

5. http://niws.nic.in/

6. https://www.darjeeling-tourism.com/darj_0000f1.htm

7. http://www.nimasdirang.com/Home/Schedule

8. http://www.iismgulmarg.in/?page_id=80 